\title{
Translation Analysis Toward Expressions Mitigating Speech Act of Criticizing in Harper Lee's Too Kill A Mockingbird and Go Set A Watchman
}

\author{
Luthfiyah Hanim Setyawati \\ Sebelas Maret University, Indonesia \\ e-mail: luthfiyahhanim456@gmail.com \\ M.R.Nababan \\ Sebelas Maret University, Indonesia \\ e-mail: amantaradja@yahoo.com \\ Djatmika \\ Sebelas Maret University, Indonesia \\ e-mail:djatmika@uns.ac.id
}

\begin{abstract}
Using descriptive qualitative method, this paper aims to identify the forms of mitigation of criticizing speech acts in sequel novels entitled To Kill a Mockingbird and Go Set A Watchman, to identify translation technique used and to describe the quality of translation of expressions mitigating speech act of criticizing in those novels. Data used were linguistic units (words, phrases, clauses, or sentences) represented mitigation types of criticizing speech act. The findings indicate that there were two mitigation types of speech act criticizing, namely external and internal. Expressions mitigating speech act of criticizing from those novels mainly had an equivalent message in Source Text (ST). Translation techniques applied to translate mitigation forms in criticizing speech act imply the translator's competence in conveying the message of Source Text. Thus, it will impact on shifting meaning or even level of politeness.
\end{abstract}

Keywords: mitigation, translation, politeness strategy, speech act of criticizing 


\section{INTRODUCTION}

A speaker that utters one of expressive speech acts, criticizing, usually has a purpose to evaluate a negative aspect of the hearer. The evaluation of criticizing is commonly based on a negative evaluation of actions, choices, sayings, and works produced by the hearer (Nguyen, 2008). Although speech act of criticizing is actually beneficial, in fact, it is often considered as an offensive thing to a person criticized. That is why (Brown, P., \& Levinson, 1987) categorizes speech act of criticizing as a Face Threatening Act (FTA). In this case, the speech act of criticizing belongs to a category of positive threatening acts that indicate the individual's desire to be accepted by others. Based on that category, a speech act of criticizing has a strong face-threatening act that needs to be mitigated. One of them is applied in syntactic forms, such as interrogative. Speech act of criticizing that is directly expressed by using evaluative adjectives with negative meanings such as "Your task score is too bad" will differ in the level of politeness when it is compared with the use of interrogative sentence "Have you checked the answer carefully after you finish it?". The use of such interrogative sentence is a mitigator on internal modification of speech act of criticizing. Lindawati (2016) states that in communication, interrogative sentences are not only uttered to ask something but they are used to express a variety of speech act. Interrogative sentences are sometimes used in order to speak indirectly (indirect speech) to maintain politeness. It can be said that it is an attempt to minimize face-threatening act to the hearer. In addition, speech acts of criticizing in various cultures, in general, cannot be uttered carelessly but it should be disclosed with appropriate strategies and basic context of socio-cultural values. This aims to avoid any conflict and smear the face of person criticized.

Speech act of criticizing should not be conveyed face-to-face, but it is also able to be conveyed through literary works. The aim is the reader does not only enjoy the plot of the story but also able to analyze the author's purpose. For example, many novel authors use their work as a medium to criticize the social problems of society in general. Harper Lee's novels entitled To Kill A Mockingbird and Go Set A Watchman are interesting sequel novels to be analyzed because it contain social criticism about racial discrimination. It can be perceived that these novels lead to express the reality of people's lives who want advancement by creating literary works as a form of constructive criticism of the restrained social values and also as an effort toward the better social order of society. Furthermore, speech act of criticizing uttered politely in the literary works must be maintained. As the translation of literary works related to social criticism, a translator needs to understand well the history of America and the issues delivered in these novels. This aims to know the translation of speech act of criticizing written by the author is conveyed by preserving the message aspect and the value of politeness of a criticism.

In relation to cross-cultural communication, a translator needs to know the forms of mitigation of criticizing speech acts and appropriate techniques in translating it. Due to the reason that translating a speech act does not only emphasize the message of the illocution of a speech but also need to consider the politeness 
message used. These kinds of messages are related opinion which explicitly mentions that mitigation is not a specific type of speech act but rather a modifying attempt aimed at reducing the effects of facial acts caused by the speech (Fraser, 1980).

Before discussing problem formulations, it is necessary to review the relevant studies to this present research in order to get novelty (something new). Many studies that examine one form of expressive speech acts, criticizing, such as (Etaywe, 2017; Frania, M., Abdul Sattar, 2015; Rohman, 2016). All these studies use a pure linguistic approach, namely sociopragmatics and Etaywe has an additional approach, namely pragmalinguistics. Frania has the similarity of discussion of criticizing speech act with the object of the book as an analysis material. The difference is that the book used as a literary work in this present study is in the form of novels, while she uses Arabic academic writing book review. For Rohman's research, he analyzes criticizing speech act found in literary work, Campursari song. Thus, it makes the difference from this present study.

Other researches (Don, Z. M., \& Izadi, 2013; Min, 2008) have relationship with this present study related to the approach. They use pragmatic approach but the objects used are different. Don and Izadi concentrate the criticizing speech act from two excerpts of talk drawn from a corpus of $12 \mathrm{Ph} . \mathrm{D}$. vivas and the second research analyzes criticizing speech act uttered between American (native speakers) and Chinese society as comparative subjects. As a result, the studies mentioned above have not linked the analysis of criticism of pragmatics theory and translation. The research on pragmatic study of expressive speech acts associated with translation, including researches of (Arvianti, 2016; Nurhidayah, 2013). The data of both studies use expressive speech acts in general. The difference is that the researcher wants to focus the research on one of the forms of expressive speech acts, namely the act of criticizing speech, in an effort to get more profound results in a speech act.

Speech act usually cannot be separated from politeness principle. Some researches on the form of mitigation (softening) of speech acts as a politeness marker has been associated with translation (Mansur, 2015). Mansur analyzes the forms of mitigation or politeness markers by using commanding speech. Pragmatics has a great contribution in translation. The contribution can be seen from two aspects, namely role and practical function. The applied approach is not a semantic translation but a communicative translation (Mansur, 2018). Thus, in fact, it is not only the directive speech act that are prone to threaten the faces of the hearer but also expressive speech, criticize, also has the same level with the directive in terms of softening or politeness. Therefore, there should be a translation study with a new object other than the directive as research material. This paper is going to identify and analyze the forms of mitigation, translation technique used and translation quality assessment from English novels entitled To Kill A Mockingbird and Go Set A Watchman in terms of the equivalence of the meaning and essence of politeness into Indonesian translations. 


\section{LITERATURE REVIEW}

Translation can be understood as a process to transfer the meaning or the idea from one language to another. This activity involves interpretation of the meaning of the text in order to produce the same meaning in another language. Translation belongs to multidisciplinary study that is able to connect with other studies as a supporting framework, such as linguistics. Since each language may or may not have a corresponding word in the other languages, linguistics study becomes a crucial thing for the translation process. At the linguistic level, translation principally focuses on issues of meaning and equivalence. The parameter of equivalence is actually related to the quality of translation called accuracy. Accuracy refers to the correspondence of messages between target languages and their source language (Nababan, M. R, Nuraeni, 2012). Meanwhile, according to Catford (1978), the equivalent translation has textually equaled. The involvement at least two different languages and cultures cause translation as complex activity. Thus, translation at linguistic level is found as the parameter in achieving the translation equivalence.

All languages are used in a particular social and cultural context. However, a translator also should pay attention to keep communication effectively, cultural essence or politeness keep going and avoid misunderstandings between writers and readers. Basically, language has certain features, such as reference, meaning, speech acts, politeness etc. Through these features, the translator has to understand what the author of the original text actually wants to convey. How translators create the same sense in target text and understand the 'what' and the 'how' of the text. As Puurtinen's statement (in Snell-Hornby, 1988) which says that "the degree of the linguistic or stylistic acceptability of a translation depends on the extent to which the translation conforms the norms and conventions prevailing in the language and style of the target literature." Therefore, the need for conformity with the rules of the target language relates to the structure of words, phrases, clauses, and sentences translated so that the results of the translation can be accepted. Sometimes a translation has a high degree of accuracy but in terms of acceptability is still very low. This is caused by the content or message of the translation is very contrary to the rules, norms or cultures applying in the community. As a result, the target reader will be reluctant to accept it. Thus, linguistics has a good approach to enhance translators' knowledge related to maintain quality of translation related to language problems. A translator is expected to maintain a linguistic equivalence between the source and the target text. Linguistics thus tries to discover 'what' and 'how' the language actually means.

Pragmatics is subfield of linguistics that examines communication. This study is concentrated on the dynamic aspect of meaning in a context of information delivery in a communication. In other words, pragmatics is the study of aspects of meaning and the use of language from speakers, hearer, other features in the context of utterances and the effects of that utterance. As the definition of Yule (2014) that gives four pragmatic definitions, namely the field that analyze (1) the meaning of the speaker; (2) the meaning in context; (3) the meaning of what is being said in communication; and (4) the form of expression based on social distance that bound 
the participants involved in a particular conversation. From this definition, it can be concluded that pragmatics studies meaning based on the speaker, the context, the intended meaning, and the participants of communication. One of the central entities in the pragmatic study is theory of speech acts proposed by Searle (1969).The theory is the development of Austin's theory that divides the speech into three forms, namely, locutionary act, illocutionary act, and perlocutionary act. In its development, Searle modified the illocutionary speech act by categorizing speech acts based on their meaning and function into five categories, namely representative, directive, commissive, expressive, and declarative.

Criticizing is one form of expressive speech acts which is often used to utter a negative evaluation of actions, choices, sayings, and works produced by the hearer (Nguyen, 2008). Speech act of criticizing can threaten the face of the hearer if the speaker expresses without any principles or politeness strategies. To express criticism, a speaker should apply one of politeness principle, the maxim of wisdom, to make the person criticized get the lowest possible losses and benefit to him as much as possible.

Mitigation is an interesting pragmatic concept for modifying an utterance. Martinovski (2006) considers that vulnerability, which may be existential or related to a particular activity or situation, is the cause of a mitigation phenomenon. Furthermore, Fraser defines that mitigation is not as a specific type of speech act but as a modification of speech acts. Both of Fraser (1980) and Holmes (1984) consider that mitigation is a strategy used to reduce the anticipated negative effects of a speech act to a hearer. It can be said briefly that the term of mitigation is adapted from Brown, P., \& Levinson's theory (1987) which is known as the face threatening act. In describing a strategy for taking threatening actions, they also state that in the context of vulnerability to the face, everyone who becomes a speaker will try to avoid these threatening actions, or going to use certain strategies to minimize threats. Thus, speakers can manifest it directly (on record) or indirectly (off record). Through explicit action, speakers involve the act of speaking in the most direct, clear, unambiguous and concise way); and with redressive action, which means the use of a strategy that will give face to the hearer an effort to avoid the potential of Face Threatening Act (FTA) with modifications such as mitigation forms. In mitigation of speech acts criticizing, Nguyen (2005) formulates two categories of mitigation forms, ie external modifications which are supporting speech put on before or after criticism and internal modifications are part of criticism and critical response. The result of formulation related to the form of mitigation of speech acts criticizing adopted from the development of House, J., \& Kasper (1981). Types of external modifications identified are (1) Steers (2) Sweeteners (3) Disarmers (4) Grounders while the internal categories consist of (1) Past tense (2) Interrogative (3) Modal (4) Hedges (5) Understaters (6) Downtoners (7) Subjectivizers (8) Consultative (9) Cajolers (10) Appealers. 


\section{RESEARCH METHODS}

\subsection{Research Design}

This research used qualitative-descriptive method to evaluate the translation of expressions mitigating speech of criticizing in Harper Lees' novels. Djajasudarma (2010) said that a research related to language aims to collect and review data and learn the phenomena of language. One of them was a phenomenon in the field of translation associated with a pragmatic approach as seen in this study.

\subsection{Sampling}

The sampling of this study was determined based on criterion-based sampling in the selection of data sources and informants. Criterion-based sampling could be called theoretical-based sampling which indicated that the data was selected and collected based on the approach or theory used. Criterion-based sampling was used as the basis for data selection and data sources in the form of translation novels entitled To Kill A Mockingbird (Lee, 1960) and Go Set A Watchmanlee (Lee, 2015) and other data sources, i.e. informants. The primary data chosen by criterion-based sampling was determined by using pragmatic theory, i.e. expressive speech acts, criticizing. Besides being used in data selection, criterion-based sampling techniques were also used in the selection of data sources in the form of novels To Kill A Mockingbird and Go Set A Watchman which involved all characters' speech mitigating criticizing speech act in the story of the novels and its translations.

\subsection{Instruments}

There were some instruments used in this research, namely document analysis (content analysis), questionnaires, and focus group discussion. In document analysis, the researcher didn't only records important contents in documents or archives, but also their implicit meaning (Sutopo, 2006). Besides, the use of questionnaire had purpose to get data related to translation quality. In accordance with the opinion of Sutopo (2006) who suggested that questionnaire is a list of questions used to collect data in research. This questionnaire was given in writing to rater with open-ended question. Rater was asked to assess the quality of the translation based on the scale of the assessment and the parameters provided by the researcher. In addition, the researcher provided a special column for comments, reasons and records regarding the quality of translation in each data. Instrument of translation quality assessment based on instrument proposed by Nababan, M. R, Nuraeni, (2012). After the questionnaire step, Focus Group Discussion (FGD) was done. Sutopo (2006) stated FGD results are the determinants of data collected using questionnaire techniques. It could be said that this activity was a discussion forum discussing the results of the questionnaire to get a mutual agreement related to the result of translation quality assessment. It aimed to make the data obtained more focused on sentences that reflect the politeness of criticism.

\subsection{Data Analysis}

Data analysis involved domain, taxonomy, componential, and culture theme analysis as described by (Spradley, 1980). Domain analysis was done by choosing 
which ones include data and not data. The researcher would identify the sentence data containing mitigation forms of criticizing speech act in the novel To Kill A Mockingbird and Go Set A Watchman and its translations. This analysis aimed to make the research more focused. The data obtained were then classified based on predetermined variables. As the opinion of Santosa (2017) which stated that the taxonomic analysis done to deepen data collection. The step of taxonomic analysis was done by the researcher by grouping the data in the form of politeness marker on speech acts criticized by Nguyen (2005), translation technique based on (Molina, L \& Albir, 2002). In this step, the researcher combined all the classified data with other components, such as the type of politeness marker, politeness marker shift and translation techniques that had been found in the taxonomic analysis. Furthermore, the results obtained were related to the impact of their use on the quality of the translations produced. The cultural theme (Finding cultural value) was seen at the relationship between the modification category shift type and the quality of translation that included accuracy and acceptability. More specifically, the researcher analyzed the underlying reasons why the mitigation forms shift from some data to such an extent and whether the shift affects the quality of the translation. In addition, the analysis of this cultural value finding data was going to know whether the shifting of mitigation forms of criticizing speech act in To Kill A Mockingbird and Go Set A Watchman reflected the author's intention in conveying the message of novels. In this case, an interview with rater was needed to answer the question why the quality of the translation caused by the modification shift in a lingual unit having a certain degree of scale.

\section{FINDINGS}

\subsection{Type of Mitigation of Criticizing Speech Act}

The first objective in this research was to identify the forms of mitigation in speech acts of criticizing found in two novels entitled To Kill A Mockingbird and Go Set A Watchman. There were 195 data of expressions mitigating criticizing speech act which were divided into two types, namely external and internal. External modifications consisted of 37 data and 158 data belong to internal modifications. Internal modifications were categorized as lexical or phrasal which consist of 6 forms, such as hedges, understaters, downtoners, subjectivizers, consultative, cajolers. In this case, appealers did not found. In category of syntactic devices consisted of four forms of mitigation, namely past tense, interrogative, modal, and tag question. Out of 14 forms of mitigation in speech act of criticizing proposed by (Nguyen, 2005), researchers found one form of mitigation, namely tag question, as effort to minimize strong criticism. The tag question was a syntactic device that was not only to express uncertainty but also having a common function as positive politeness: to weaken or mitigate the force of an utterance. (Holmes, 2001) described four different functions of tag questions by the use of features such as hesitations, qualifiers, tag questions, empty adjectives, and other properties. They are expressing uncertainty, facilitative, softening, and confrontational. Besides, he also stated that tag question is able to soften the critical comment. Thus, total of mitigation of criticizing speech act was 14 forms, as seen in the table: 
Table 1: Recapitulation of Type of Mitigation of Criticizing Speech Act

\begin{tabular}{|c|c|c|c|c|c|}
\hline \multirow{2}{*}{\multicolumn{2}{|c|}{$\begin{array}{l}\text { Type of Mitigation of } \\
\text { Criticizing Speech Act }\end{array}$}} & \multicolumn{2}{|c|}{ Frequency } & \multirow[t]{2}{*}{$\sum$} & \multirow[t]{2}{*}{$\%$} \\
\hline & & TKAM & GSAW & & \\
\hline \multirow[t]{4}{*}{ External } & Sweeteners & 7 & 4 & 11 & 5.7 \\
\hline & Disarmers & 9 & 2 & 11 & 5.7 \\
\hline & Grounders & 6 & 3 & 9 & 4.6 \\
\hline & Steers & 3 & 3 & 6 & 3 \\
\hline \multirow[t]{10}{*}{ Internal } & Interrogative & 22 & 20 & 42 & 21.6 \\
\hline & Hedges & 17 & 9 & 26 & 13.3 \\
\hline & Subjectivizer & 13 & 10 & 23 & 11.8 \\
\hline & Cajolers & 12 & 3 & 15 & 7.7 \\
\hline & Taq Question & 9 & 3 & 12 & 6.1 \\
\hline & Modal & 7 & 5 & 12 & 6.1 \\
\hline & Understaters & 8 & 3 & 11 & 5.7 \\
\hline & Past Tense & 5 & 3 & 8 & 4 \\
\hline & Downtoners & 5 & 2 & 7 & 3.6 \\
\hline & Consultative & 2 & - & 2 & 1 \\
\hline Total & & 125 & 70 & 195 & 100 \\
\hline
\end{tabular}

The classification of expressions mitigating speech act of criticizing in those novels showed that the dominance appearance was internal type of mitigation which appear in the form of interrogative for 42 data or $21.6 \%$. Hedges were employed 26 data or $13.3 \%$, such as well, sort of, kind of, more or less, somehow, such, now. Subjectivizers are found 23 data or $11.8 \%$, for example: I guess, I dont' think, I think, I reckon, I Idont' reckon, I am confident, I wondered, I believe. Cajolers are 15 data or $7.7 \%$, such as you know, I mean, What I meant was, you see, don't you see. Tag questions and modals were 12 data or 6.1\%. Understaters (such as merely, just, simply, really) and external type of sweeteners and disarmers 11 or $5.7 \%$, followed by grounders which appear 9 data or $4.6 \%$. Past tense consisted of 8 data or $4 \%$, downtoners 7 data or 3.6\%, such as maybe, probably. Steers consisted of 6 data or $3 \%$, and the last was consultative such as Do you think? Do you agree? which was the fewest of all the data as found only 2 data or $1 \%$. The precise nature and politeness functions of both external and internal modifications were contextspecific, i.e these devices were not inherently polite but might derive their politeness value when employee in certain situations (Bella, 2011). As the statement, the speech act of criticizing on these novels showed the politeness aspect represented by characters in the novel in some context of situation, such as critique uttered between parents and children, black people and white people, and critique uttered in a court. These examples were representation each category of external and internal modification. The first example is external type of mitigation sub category sweeteners extracted from chapter 9, page 116 on ST, page 131-132 on TT.

ST: "you had the right answer this afternoon, but the wrong reasons.

TT: "kau mendapatkan pengetahuan yang benar sore ini, tetapi dengan alasan yang salah. 
Context: Jack (Scout's uncle) has just scolded Scout for her abusive speaking to others but according to Scout, he should have asked why he talked like that. Jack then felt guilty because Scout's reason related such impolite thing is caused by insults directed to his father as a Nigger lover. Atticus felt that his brother had done the right thing instead of Jack regretting scolding her.

Softening the speech used in this data belongs to a mitigation device of external modification, sweetener. Sweetener is a compliment or positive expression given to a speaker before or after criticism or to compensate for offensive measures (Nguyen, 2005). In the above example, the right answer is a phrase used as a speech act of criticizing of Atticus to his young brother, Jack. Atticus's criticism shows the statement of problem directly but he chooses to speak indirectly by praising before criticizing in order to reduce the power of strong criticism.

The data below is an example of internal type of mitigation sub-category interrogative found in chapter 1, page 16 on ST, page 23 on TT in Go set A Watchman:

\section{ST: "Yes, but don't you see you'll never catch a man that way?" \\ TT: "Ya, tapi tidakkah kau mengerti, kau tak akan pernah mendapatkan pendamping jika terus begitu?"}

Context: Calipurnia criticizes Jem's actions for bringing underage girls, his daughter, to the trial of rape cases. According to her, it is not worth witnessed by underage girls.

This form of mitigation is the most finding in the category of internal modification of speech acts criticizing. Indeed, the interrogative form is the safest way to minimize face threatening act that can be applied in the form of indirect speech acts. It can be identified that the bold letters in ST is a form of sentence as an attempt to mitigate criticism. Although in the context of the situation Calipurnia's words express the criticism directly but she is still trying to refine his criticism by using the interrogative form as a manifestation of politeness to his employer. In terms of translation, utterance in ST is still maintained by the translator at the same structure. Although a change in translator's point of view in the ST translation is exist, it does not change the message and essence of politeness to TT (Target Text).

\subsection{Translation Techniques}

There are 18 types of translation techniques introduced by Molina, L \& Albir (2002). From the identification of translation techniques, there is combination of techniques used in reconstructing expression mitigating criticizing speech act.

Table 2: Types of Translation Techniques in Reconstructing Expressions Mitigating Criticizing Speech Act

\begin{tabular}{lccc}
\hline \multirow{2}{*}{$\begin{array}{c}\text { Type of Mitigation of Criticizing } \\
\text { Speech Act }\end{array}$} & \multicolumn{2}{c}{ Frequency } & \\
\cline { 2 - 3 } & TKAM & GSAW & \\
Established Equivalence & 175 & 166 & 341 \\
Variation & 36 & 31 & 67 \\
Modulation & 26 & 11 & 37
\end{tabular}




Naturalized Borrowing
Explicitation
Deletion
Discursive Creation
Transposition
Literal
Implication
Adaptation
Adition
Particularization
Generalization
Reduction
Compensation

$\begin{array}{ccc}12 & 5 & 17 \\ 7 & 10 & 17 \\ 11 & 6 & 17 \\ 6 & 1 & 7 \\ 4 & 2 & 6 \\ 2 & 3 & 5 \\ 1 & 2 & 3 \\ 2 & - & 2 \\ 1 & 1 & 2 \\ 1 & 1 & 2 \\ 1 & - & 1 \\ 1 & - & 1 \\ 1 & - & 1\end{array}$

This example below is data of translation technique used to translate expression mitigating speech act of criticizing found in To Kill A Mockingbird chapter 24, page 308 on ST, page 327 on TT.

ST: "Well, you won't get very far until you start wearing dresses more often."

TT: "Hm, kamu tak akan berhasil sampai kamu mulai lebih sering mengenakan rok.”

Context: Miss Stephanie criticized Miss Maudie's statement representing Scout's answer regarding her desire to be a lady, not a lawyer as she thought. She says that Scout can be a respectable lady if her current appearance is transformed into a real girl, by wearing a skirt instead of pants.

The translator selects established equivalent technique so that the expression translates to "Hm". Established equivalent is commonly a translation technique commonly used terms as well as terms in the target language dictionary. As we know, the expression "hm" has been widely used by Indonesians as one of the efforts to soften the speech. It turns out to have the same effect on the quality of translation. When this hedge is omitted or ignored in speech, it can create the impression of a less polite, offensive, arrogant speaker, so that speech does not feel right (Fraser, 2010: 15). Hedge contained in ST is an expression of Miss Stephanie to keep courtesy to her friend, Miss Maudie. This form of mitigation shows a speaker's caution with limits in a criticism.

Another example found in To Kill A Mockingbird chapter 18, page 244 on ST, page 259 on TT, as follows:

ST: I wondered if anybody had ever called her "ma'am," or "Miss Mayella" in her life; probably not, as she took offense to routine courtesy.

TT: Aku bertanya-tanya apakah pernah ada orang yang memanggil Mayella dengan sebutan "Miss" atau "Miss Mayella" seumur hidupnya; mungkin tak pernah sehingga dia tersinggung oleh kesopanan biasa ini. 
Context: Scout criticized Mayella's behavior because she is angry if Atticus called her Miss. According to him, the call is not to mock but as a manifestation of decency.

As seen in the data above, the phrase is a past tense but the translator eliminates the context of the time referent to word "bertanya-tanya" in its translation. To get equivalence translation of ST message, the translator should add 'aku bertanya-tanya' translation with "tadinya aku berpikir" as an attempt to bring up the time referent message in the source text. In the data analysis, there is a missing message due to the translator using the deletion technique. This form of mitigation includes an Embedded question, which means a question (can be either a question or a yes-no question) in a declarative statement or another question. Critics deliberately use the form of mitigation in a more polite question marked by the phrase "I wondered".

This example is found in chapter 19, page 266 on ST, page 283 on TT in novel To Kill A Mockingbird.

ST: "That's just Mr. Gilmer's way, Dill, he does 'em all that way. You've never seen him get good'n down on one yet.

TT: "Itu cuma gaya Mr. Gilmer, Dill, dia memperlakukan semua saksi seperti itu. Kau belum pernah melihatnya benar-benar galak.

Context: Dill criticized the treatment of a lawyer named Mr. Glimer from the Ewell family who always called Tom as 'boy' and grinned at him. According to him, it is not fair because of the Atticus itself treat them well.

In the translation of this expression, the translator uses discursive creation technique that has an effect on non-equivalence message. It would be worth it if adverb "just" mitigation form is translated into "memang" because in its use "just" is not meaningful only or "cuma". However, the rules of the source language remain well conveyed because "hanya" is usually used as an informal language according to the context in which the above criticisms are made by his own friends. Understaters are lexical tools oriented to the core of speech. The data above is a direct criticism of speech that is marked by the expression of disapproval of Dill's anger with Mr. Glimer. The criticism is modified by adding "just". The addition of lexical devices in the form of adverb "just" is categorized in the speaker's efforts not to exaggerate the problem. This shows Dill's indifference to the attitudes of lawyers or prosecutors in court. The application of the form of understaters is also considered as a politeness strategy in order to keep the face of the speaker or the other person from the face-toface action directly by the speaker. This form is usually an Adverbial Modifier like a little (bit), some, few, not very (really), not many (enough), almost, slightly, just / only, quite / rather (Nguyen, 2005).

Another example the use of discursive creation result the quality of translation as follow: 
Shifting on internal type of mitigation sub category interrogative in a speech act of criticizing of To Kill A Mockingbird chapter 21, page 277 on ST, page 295 on TT

ST: Mister Jem, don't you know better'n to take your little sister to that trial?

TT: Mister Jem, mestinya kau tahu, adikmu tidak boleh dibawa ke pengadilan itu.

Context of situation: Calpurnia criticized Jem for his actions that brought his sister, underage girl, to see trial of rape case in court.

The example above occurs shifting on the form of sentence. Interrogative sentence from ST change into declarative sentence in TT. This occurs as a result of discursive creation technique applied. After assessing the data, this data is not accurate but good quality in the accurate aspect.

\subsection{The Assessment of Translation Quality}

Instrument of translation quality was assessed by accuracy, acceptability, and readability (Nababan, M. R, Nuraeni, 2012). In this present study, the quality of the translation is assessed only in terms of accuracy and acceptability because the translation data are words, phrases and clauses. Thus it does not need readability assessment. An accuracy assessment is obtained by providing information about the source language, target language, and context of the situation which are going to be compared whether messages from the source language are well conveyed in the target language taking into account the context of the situation in the criticisms. Meanwhile, in the assessment of acceptability, rater read the target language by considering the aspects of the naturalness of translation based on the rules of the target language and culture. The accuracy is assessed in score 3-2-1. Good accuracy is marked by score 3, less accuracy is 2 , and not accuracy is 1 . These rates also occur for accessing acceptability. Rate 3 is marked for good acceptability, 2 is less acceptability, 1 is not acceptability. Raters' assessment result then classified into range of translation quality, as follow:

Table 3: The Range of Score on Quality Translation Assessment

\begin{tabular}{|ccc|}
\hline No. & Category & Range of Score \\
\hline $\mathbf{1}$ & $\begin{array}{c}\text { Accurate, Acceptable, high } \\
\text { readibility }\end{array}$ & $2.6-3.0$ \\
\hline $\mathbf{2}$ & $\begin{array}{c}\text { Medium accuracy, acceptability, and } \\
\text { readability }\end{array}$ & $2.0-2.5$ \\
\hline $\mathbf{3}$ & $\begin{array}{c}\text { Not accurate, Not acceptable, low } \\
\text { readability }\end{array}$ & $0.0-1.9$ \\
\hline
\end{tabular}

After accessing the data based on raters, the researcher was able to conclude range of translation quality of expressions mitigating speech act of criticizing as table follow: 
Table 4: Recapitulation of Translation Quality of Expressions Mitigating Criticizing Speech Act

\begin{tabular}{|ccccc|} 
No. & $\begin{array}{c}\text { Type of Speech Act } \\
\text { of Criticizing } \\
\text { Mitigation }\end{array}$ & Quality Category & $\begin{array}{c}\text { Total average } \\
\text { score }\end{array}$ & Score \\
\hline \multirow{2}{1}{} & External & Accuracy & $11.81: 4$ & \\
\cline { 2 - 5 } & Acceptability & $11.7: 4$ & 2.95 \\
\hline $\mathbf{2}$ & Internal & Accuracy & $25.22: 10$ & 2.52 \\
\cline { 3 - 5 } & & Acceptability & $25.59: 10$ & 2.59 \\
\hline
\end{tabular}

From the table above, it could be concluded that the translation quality of expressions mitigating speech act of criticizing in two Harper lee's novels entitled To Kill A Mockingbird and Go Set A Watchman had not achieved the best quality on internal type of mitigation. It was proved that the result only achieved the average score 2.52 on accuracy and 2.59 on the acceptability. Thus, it meant that the result was on the level of medium. Besides, on external type of mitigation, it achieved good quality in accuracy and acceptability. The acceptability was the second assessment of quality of translation and got a constant score. This aspect considered the cultural background of target language. However, if the calculation for all types of mitigation speech act of criticizing were counted, it resulted the good quality in accuracy and acceptability. Both of types resulted the score of accuracy at 2.73 and the score of acceptability at 2.75 .

\section{DISCUSSION}

This section will describe the relationship between the components between the forms of mitigation in speech act of criticizing, translation techniques used, and the quality of the translation. As mentioned earlier that two types of mitigation of speech act of criticizing, namely external and internal. The findings showed that internal mitigation forms found frequently rather than external ones. This indicates that the American society tends to be open-ended in expressing criticism as seen in the realization of criticisms of speech that tend to criticize directly. Nonetheless, a literary work with a genre of social criticism substantially as well as its language use has to remain attentive to the values of politeness. Through the literary works, the criticism should be based on a sense of care rather than hate. The hatred embodied in criticism will only hurt others or even himself. Based on the period, the analyzed novel was published in the 1960s which at that time has emerged human rights movements at the same time became the peak of the growth of literacy in America. Joyce (1983) states that spurred on by the social and cultural advances of the late1950s and 1960s, and an increased demand for books by and about AfricanAmericans, the period 1960-80 saw the largest increase in new African-American book publishers in the 20th century. To Kill A Mockingbird and Go Set A Watchman include some titles released by African-American book publishers, and these works addressed to a subject of racism problem. The significance of authors' role as intermediaries in the circulation of ideas within society at the time was primary 
importance to many African-American book publishers to foster American culture through intellectual and literary products. Thus, book publishers serve those authors related their works and publish it. Therefore, American society at that time chose to comment on social problems that occurred through criticisms in the literary work. Speech act of criticizing uttered politely in the literary works must be maintained. Furthermore, in the translation of literary works of social criticism, a translator needs to understand well the history of America and the issues delivered in the novel. This aims to know the translation of speech act of criticizing written by the novelist is conveyed by preserving the message aspect and the value of politeness of a criticism.

In the internal category, there are two forms of mitigation belong to syntactic and lexical categories. Lexical categories appear much data than syntactic categories. The data finding shows 74 syntactic and 84 lexical forms. The form of syntactic mitigation has good enough score assessment or even not accuracy and acceptability, especially in the form of 'past tense' and 'modal'. This is due to the inappropriate use of translation techniques. In the Past Tense mitigation form, the translator uses the deletion technique in translating it. To make the translation accurate and acceptable, the translator should use a grammatical sentence that refers to the past, but the resulting translation eliminates the characteristics of past tense so that the quality of the data in terms of accuracy and acceptability is only worth 1 score. In the form of mitigation called Modal has a less accurate quality and acceptable. This is due to the use of several techniques, such as deletion techniques, discursive creations and also literal. For this mitigation form, the quality of the translation is less accurate and acceptable due to the use of the deletion technique. However, the culture of the target language influences a translator to ignore time reference and sometimes it is influenced by lack of 'modality' types. In line with Grangé (2010), he states that in Indonesian, a wealth of aspectual and modal meanings can be expressed by about fourteen pre-verbal grammatical morphemes, called "markers". These aspect markers are distinct from time adjuncts, (although aspect markers can lead in absentia to localization in time). Modality meanings are also conveyed by most of the aspect markers. Languages such as English rely mainly on verbal moods, a system that needs lexical helpers to express numerous aspectual and modal nuances. For the reason, the deletion technique is used by the translator as consideration. For the form of Modal, the translation quality obtained is greater acceptability than the accuracy. This is due to the use of deletion techniques and discursive creations on aspects of accuracy. While acceptance gets a less acceptable score is due to the use of deletion techniques. In addition, lexical forms that have low accuracy and acceptability are Downtoners. This is due to the use of deletion techniques. The 'possible' mitigation forms are omitted in the present finding. In addition, the use of deletion techniques and discursive creation in translating forms of mitigation Understaters is also found. The use of deletion techniques was found twice and discursive creations 1 times of 11 data. Although most use established equivalence techniques, discursive creations techniques affect the translation quality in terms of accuracy. Obtaining score quality of translation 
accuracy becomes less accurate, although from the aspect of acceptability has acceptable results.

In the external category, the most frequently finding are Disarmers. This result has opposite result from Frania, M., Abdul Sattar (2015). This category includes the fewest category found. In the other hand, similar finding with Frania's research, Sweetener is is also frequently found when mitigating a criticism comment. In (Etaywe, 2017), he also found sweetener uttered in the form of praise. He argues that 'praise-criticism clausal pairing' refers to instances where full illocutionary force of specific criticism was alleviated through the juxtaposition of direct negative comments to praise, or by making praise syntactically subordinated to a criticism clause. The praise-criticism adjacency softens the negativity of evaluation. The findings of mitigation forms have an accurate and acceptable quality of translation quality. Each of the categories commonly uses established equivalence techniques in translating the expressions that mitigate speech act of criticizing. In addition to the prevalent common equivalent techniques, there are several other techniques used in translating mitigation forms in this external category, including Variation, Modulation, Literal, Naturalized Borrowing, Transposition, Explicitation, Generalization, Implicitation, and Adaptation techniques. However, the use of literal techniques in the form of mitigation of Sweeteners impact on the inaccuracies and acceptance of speech act of criticizing. The external category is a wider lingual unit than the internal category because the utterance put on the pre or post-criticism. Therefore, the techniques used are more than one type.

\section{CONCLUSION}

Based on the above analysis, it can be concluded that mitigation is an effort to modify speech acts that serves to avoid self-speech participants from facial acts. In its use, pragmatics is an approach that is able to explain the phenomenon of mitigation that occurs in communication as a form of application of principles and strategies of politeness in speech acts. Much of the expression data that mitigates the act of speech criticizing found is a category of internal rather than external modification. In terms of the sub-category of mitigation forms of speech acts criticizing, the interrogative is mainly the most strategy used. This suggests that Americans prefer to express criticism or judgment in a solid and clear way rather than long-winded before criticizing. Nevertheless, the density of the delivery of criticism is still pursued in a polite manner. Most of the expression translation data that mitigate speech acts criticize from the novels To Kill A Mockingbird and Go Set A Watchman still maintain the messages from ST so that the forms of politeness criticize the characters can still give a good impression for readers.

Related results and discussions presented, the researchers provide recommendations to teachers or lecturers to provide materials to raise awareness to language learners will need to master pragmatic competence. This competency can later be used to compare the politeness of expressive speech acts in each culture. In addition, pragmatic competence can also be considered for translation practice. For the reason, in order to produce a quality translation result on expressions that mitigate expressive speech or other speech acts, the translator should be able to 
maintain the character's impression in the novel as evidenced by maintaining the essence of politeness and the message of the source language. In short, this pragmatic competence is closely related to the world of language education as well as translation.

\section{REFERENCES}

Arvianti, G. F. (2016). Tindak Ilokusi Ekspresif Dalam Komik Big Bad Wolf: The Baddest Day dan Terjemahannya. Jurnal Bahasa, Sastra Dan Pengajarannya, 12(1), 98-106. https://doi.org/10.31002/transformatika.v12i1.203

Bella, S. (2011). Mitigation and politeness in Greek invitation refusals: Effects of length of residence in the target community and intensity of interaction on non-native speakers' performance. Journal of Pragmatics, 43(6), 1718-1740. https://doi.org/10.1016/j.pragma.2010.11.005

Brown, P., \& Levinson, S. C. (1987). Politeness: Some Universals in Language Usage. Cambridge: Cambridge University Press.

Catford, J. C. (1978). A Linguistic Theory of Translation. London: Oxford University Press.

Djajasudarma, T. F. (2010). Metode linguistik: ancangan metode penelitian dan kajian. Bandung: Refika Aditama.

Don, Z. M., \& Izadi, A. (2013). Interactionally achieving face in criticism-criticism response exchanges. Journal of Language and Communication, 33(3), 221231. https://doi.org/10.1016/j.langcom.2013.05.003

Etaywe, A. S. (2017). A Pragmalinguistic and Sociopragmatic Study of Praise and Criticism in Academic Writing: The Case of Arabic Academic Book Reviews. International Journal of Humanities and Cultural Studies, 4(2), 87-121. Retrieved

from https://www.ijhcs.com/index.php/ijhcs/article/download/3127/2927

Frania, M., Abdul Sattar, H. Q. (2015). A Sociopragmatic Analysis of the Speech Act of Criticism by Persian Native Speakers. International Journal of Humanities and Cultural Studies, 2(3), 305-324. Retrieved from https://www.ijhcs.com/index.php/ijhcs/article/viewFile/384/385

Fraser, B. (1980). Conversational Mitigation. Journal of Pragmatics 4, 341-350 http://dx.doi.org/10.1016/0378-2166(80)90029-6. Journal of Pragmatics, 4(4), 341-350. https://doi.org/https://doi.org/10.1016/0378-2166(80)90029-6

Grangé, P. (2010). Aspect and modality in Indonesian The case of sudah, telah, pernah, and sempat. Wacana, Journal of the Humanities of Indonesia, 12(2), 243. https://doi.org/10.17510/wjhi.v12i2.117

Holmes, J. (1984). Modifying Illocutionary Force. Journal of Pragmatics, 8, 345365.

Holmes, J. (2001). An Introduction to Sociolinguistics. LONDON: Longman.

House, J., \& Kasper, G. (1981). Politeness Markers in English and German. Rasmus Rask Studies in Pragmatic Linguistics, 2(Conversational Routine). https://doi.org/10.1515/9783110809145.157

Joyce, D. F. (1983). Gatekeepers of Black Culture: Black-Owned Book Publishing in The United States, 1817-1981. Westport, CT: Greenwood Press. 
Lee, H. (1960). To Kill A Mockingbird. New York: J.B. Lippincott \& Co.

Lee, H. (2015). Go Set A Watchman. United Stated: HarperCollins.

Lindawati. (2016). Indonesian Interrogative Sentences: a Study of Forms and Functions. Journal of Humanities, 28(3), 348-357. Retrieved from https://jurnal.ugm.ac.id/jurnal-humaniora/article/download/22289/14980

Mansur, A. A. (2015). Mitigasi: Upaya Penghalusan Tuturan Sebagai Wujud Strategi Kesantunan. Diglossia, Jurnal Kajian Kebahasaan Dan Kesusatraan, 7(1), 1-12. https://doi.org/http://dx.doi.org/10.26594/diglossia.v7i1.393

Mansur, A. A. (2018). Kontribusi Pragmatik dalam Penerjemahan: Peranan dan Fungsi Praktis. Jurnal Kajian Ilmiah Kebahasaan Dan Kesusastraan, 9(2), 97-107. https://doi.org/http://dx.doi.org/10.26594/diglossia.v9i2.1140

Martinovski, B. (2006). A framework for the analysis of mitigation in courts: Towards a theory in mitigation. Journal of Pragmatics, 38(12), 2065-2086.

Min, S. C. (2008). on the differences of speech act of criticism in Chinese and English. US-China Foreign Language, 6(3), 74-77.

Molina, L \& Albir, A. H. (2002). Translation Techniques Revisited: A Dynamic and Functionalist Approach. Meta: Journal Des Traducteurs, 47(4), 498. https://doi.org/10.7202/008033ar

Nababan, M. R, Nuraeni, \& S. (2012). Pengembangan Model Penilaian KualitasTerjemahan. Kajian Linguistik Dan Sastra, 24(1), 39-57.

Nguyen, M. T. T. (2005). Criticizing and Responding to Criticism in A Foreign Language: A Study of Vietnamese Learners of English. University of Auckland. Retrieved from http://www.researchgate.net/publication/37984689_Criticizing_and_respondin g_to_criticism_in_a_foreign_language_A_study_of_Vietnamese_learners_of_ English?enrichId=rgreq-56146bfa-2b06-469d-9430-

Nguyen, M. T. T. (2008). Criticizing in an L2: Pragmatic strategies used by Vietnamese EFL learners. Intercultural Pragmatics, 5(1). https://doi.org/doi:10.1515/ip.2008.003

Nurhidayah, V. A. (2013). An Analysis Of Translation Techniques And Quality In Terms Of Accuracy, Acceptability, And Readability Of Pi's Expressive Speech Act In The Film Entitled Life Of Pi. PRASASTI: Journal of Linguistics, 2(2), 67-79. https://doi.org/10.20961/prasasti.v2i2.338

Rohman, N. (2016). Pemanfaatan Aspek Stilistika Pragmatik Sebagai Strategi Mengkritik Dalam Wacana Lirik Lagu Campursari. Universitas Gajah Mada.

Santosa, R. (2017). Metode Penelitian Kualitatif Kebahasan. Surakarta: UNS Press.

Searle, J. R. (1969). Speech Act An Essay in the Philoshophy of Language. Cambridge: Cambridge University Press.

Snell-Hornby, M. (1988). Translation Studies: An Integrated Approach. Amsterdam/ Philadelphia: John Benjamins Publishing Company.

Spradley, J. P. (1980). Participant Observation. Participant Observation. https://doi.org/10.1017/CBO9781107415324.004

Sutopo, H. B. (2006). Metodologi Penelitian Kualitatif: Dasar teori dan Terapannya dalam Penelitian. Surakarta: UNS Press.

Yule, G. (2014). Pragmatics. Oxford: Oxford University Press. 
Translation Analysis Toward Expressions Mitigating Speech Act of Criticizing 